\title{
E-LEARNING IN STUDENT EDUCATION
}

\author{
Marta Woźniak*, Krakowska Akademia im. Andrzeja Frycza Modrzewskiego \\ Mariusz Grzyb ${ }^{* *}$, Krakowska Akademia im. Andrzeja Frycza Modrzewskiego \\ Sebastian Rymarczyk ${ }^{* * * *}$, Krakowska Akademia im. Andrzeja Frycza Modrzewskiego
}

\begin{abstract}
In this article the authors reflect on what is distance education. The authors show conditions for distance education implementation. The article shows the barriers to the implementation of e-learning at universities. The article also shows how the information society results in the development of e-learning. Then the article shows a distance learning - case study of Andrzej Frycz Modrzewski Krakow University elearning platform.
\end{abstract}

Key words: distance learning, e-learning at university, e-learning platform

JEL classification: A22

\section{ELEKTRONSKO UČENJE U OBRAZOVANJU STUDENATA}

Sažetak: U ovom radu autori se bave učenjem na daljinu. Autori ukazuju na uslove pod kojima se primenjuje učenje na daljinu. Rad ukazuje $i$ na prepreke ka primeni elektronskog učenja na univerzitetima. Takođe, rad prikazuje način na koji informacijsko društvo rezultira razvojem elektronskog učenja. Zatim, rad prikazuje učenje na daljinu - studiju slučaja platforme za elektronsko učenje univerziteta Andrej Frič Modževski iz Krakova.

Ključne reči: učenje na daljinu, elektronsko učenje na univerzitetu, platforma za elektronsko učenje

\footnotetext{
Marta Woźniak, E-Learning Center manager, Coordinator of e-Learning project 'Internationalization of Krakowska Akademia im. Andrzeja Frycza Modrzewskiego', e-learning specialist in the project ' 2.0 Enterprise Postgraduate studies for business'

Mariusz Grzyb, E-Learning Center graphic designer, graphic specialist for 'Internationalization of Krakowska Akademia im. Andrzeja Frycza Modrzewskiego", supervisor, author of EMarketing major for ' 2.0 Enterprise Postgraduate studies for business project

**** Sebastian Rymarczyk, administrator of e-learning platform at E-Learning Center, Administrator of e-learning platform for ' Internalization of Krakowska Akademia im. Andrzeja Frycza Modrzewskiego' project, Administrator of e-learning platform for '2.0 Enterprise Postgraduate studies for business' project.
} 


\section{WHAT IS DISTANCE EDUCATION?}

E-learning, blended learning, distance learning, distance education... What differentiates all these modes and what terminology should be used to explain what is meant by delivering education over a distance? Firstly, is it distance learning or distance education? Education is an activity performed individually or under somebody's guidance. The main aim of such activities consists of obtaining a certain amount of knowledge about the surrounding environment, about oneself, which leads to the development of one's interests and abilities. Education aims at creating human being attitudes oriented at comprehensive intellectual development, and at stimulating the need for constant selfdevelopment and independent acquisition of knowledge and skills [4]. Teaching is often defined as the mode of supervising the learning process, as a planned and systematic work of a teacher with a student, aiming at obtaining skills and knowledge as well as at developing student's abilities and interests. Thus, it can be concluded that education is a broader term, which not only comprises the process of knowledge and ability acquisition but also brings to one's attention the need for intellectual self- development.

In case of work with students the didactic process is not just teaching. Working with students is an education process which involves the transfer of knowledge and skills as well as consolidating the attitude of intellectual open-mindedness accompanied by the awareness of the necessity of systematic and independent self education. Blended - learning or e-learning? This question requires an answer. E-learning is a mode of delivering education over a distance by means of the Internet. M. Hyla's definition of e-learning is the most frequently quoted illustration of what e-learning is. According to his definition e-learning can be described as 'electronic data inventory intended for independent use and equipped with navigation elements' ${ }^{1}$. Such definition may cause some difficulties; nevertheless it illustrates the essence of this type of course. Blended-learning is a combination of traditional classes, during which a teacher meets students, with an Internet course using multimedia techniques. Elearning is an education process over a distance. However, in academic education context, distance education may play a complementary role, facilitating traditional classes. Therefore, what we experience is distance learning understood as blended-learning.

\section{CONDITIONS FOR DISTANCE EDUCATION IMPLEMENTATION}

In order to implement distance education several issues need to be considered. The most important of them are the choice of the e-learning platform, training

\footnotetext{
${ }^{1}$ Marek Hyla, Przewodnik po e-learningu, ABC a Wolters Kluwer business, Warszawa 2007r
} 
of the staff responsible for creating and moderating the courses and following the requirements imposed by appropriate regulations. An appropriate e-learning platform is adjusted to the needs of its users. Therefore, an e-learning platform should be correlated with the specificity of the teacher-student cooperation as well as to the types of teaching materials that are to be presented to students. Also, at the very early stage of the process it may be determined that the courses should be available to the students on a platform according to the schedule provided by a teacher. Students should know at the very beginning of the semester the scope of the material that they will have to master and the timetable for using the material. The courses should consist of texts, examples, illustrations as well as of interactive activities helping students to check their progress. A student needs to have a possibility to use the materials several times in order to revise and consolidate the topics discussed in the course. Apart from interactive courses, a teacher should be given the possibility of assigning homework to be done either individually by students or in teams, the result of which ought to be presented on the platform, e.g. for getting teacher's assessment. At any time a teacher must have an opportunity to present additional material to the students, for instance reports, articles or examples.

It is essential that a platform should not be a place meant only for delivering a course, even an interactive one, and checking if it has been completed by a student. E-learning platform must provide space for student-teacher communication, for consultation and the exchange of thoughts and opinions. Therefore, it is very important that the work on the platform should be both synchronic and a-synchronic. In order to ensure the presence of chat modulesenabling the exchange of ideas within a group, between the students and a teacher- a moderator in a synchronic mode, there should be a forum- a chat in an a-synchronic mode, and also there should be a video-conference modesynchronic communication during which, apart from talking and writing in a real time, a teacher and students are able to hear and see each other. A videoconference makes it possible to deliver a lecture or consultation without having to gather all the participants in one place.

Another key issue to be mentioned concerns the way of preparing the materials for students. Materials for e-learning should not be book-like. While preparing them one should avoid copying book contents, since they do not differ from a book only by the lack of page turning. E-learning course generators provide the authors with a variety of attractive didactic forms. They allow authors to plan and implement various education paths and approaches, depending on the choices made on the screen by a learner. They make it possible to enrich the syllabus with new and surprising elements such as tests, quizzes - the main purpose of which is to facilitate and systematize knowledge acquisition. Course authors should have the chance to use the help of e-learning specialists in 
teaching methods who know how to prepare the teaching content in a mode attractive for students. Specialists in teaching methods, thanks to their professional experience, are capable of keeping distance and having a fresh look at the content prepared by course authors and in this way can help them plan and organize the e-learning process.

The authors of the courses, most of whom will later become course moderators, should also be given an opportunity to broaden and improve their course preparing skills. A school introducing e-learning courses ought to make it possible for course authors to participate in training session comprising the technical aspects of course preparation- that is the tools they can resort to in their work. Additionally, there should be trainings in course preparation methods and copyright law. Academic teachers, or course moderators, need to be trained for working with students on e-learning platforms, especially with regard to material presentation, moderating forum discussions, chat discussions, ways of motivating students for work. Also students should undergo e-learning training, how to use the platform, how to communicate with teachers via the platform.

Another issue concerning the implementation of e-learning involves its legal regulations. Such implementation of e-learning by a higher education institution involves meeting conditions defined by certain regulations. Therefore, an environment analysis, aiming at checking the fulfillment of the conditions required by an appropriate regulation for delivering distance education, must be conducted. Following an appropriate regulation, a higher education institution should employ teaching staff trained for conducting didactic activities involving distance education methods and techniques. There is another condition namely the access to IT infrastructure and software, which enables synchronic and asynchronic interaction between students and teachers. The school is obliged to provide didactic materials in an electronic form. What is more, the school must provide every student with a chance of having personal consultations with a teacher on school's premises. The last but not the least condition concerns the methods of checking progress. 'Higher school shall guarantee current progress checks, knowledge and skills verification, via administering tests and exams in a particular subject on school's premises. ${ }^{2}$,

The last condition is concerned with providing the current supervision of course teachers. Additionally, according to the recent regulations "the number of didactic hours for day and extramural students, involving distance education methods and techniques, must not exceed $60 \%$ of the total number of didactic

\footnotetext{
${ }^{2}$ Minister of Science and High Education's order of September 25th 2007 with supplement on conditions the fulfillment of which is necessary for conducting didactic activities using distance education methods and techniques, Law Gazette. Nr 188, item.1347, p. 1
} 
hours as defined in the education standards for particular studies and levels of education, laboratory and training classes excluded." Therefore, it is vital that in the process of implementation of on-line activities, a system of principles and rules on how to conduct classes with the elements of distance education methods and techniques is drawn up, as it will lead to an efficient coordination of the remote controlled education process.

\section{BARRIERS TO THE IMPLEMENTATION OF E-LEARNING AT UNIVERSITIES}

While introducing the subject of e-learning at universities, two clearly noticeable barriers - the technical and mental - should be taken into account. As far as the technical aspects are concerned, the main problems are connected with providing proper infrastructure in terms of hardware and software. The selected equipment should enable the smooth use of an e-learning platform with a large number of users accessing it at the same time. On the other hand, the elearning platform should be selected in such a way so that it is possible to use it with the equipment available to a potential group of users.

The mental barrier applies to both students and lecturers, though in the case of students, it is a rather marginal problem. For students, these are mostly the problems associated with the need to learn how to use a new tool, that is, the e-learning platform. However, students are excellent at navigating in the world of social networking and instant messaging, so learning how to operate on a new system will not take them long. It is lecturers, especially the senior staff, who are faced with problems connected with introducing e-learning in their teaching mode. University teachers must not only learn how to use an e-learning platform, but also how to take advantage of the tools needed to prepare individual courses. In addition, both students and lecturers who are accustomed to traditional forms of education, while starting to use the e-learning platform, must overcome their doubts concerning effectiveness of this new form of education and learn how to effectively use the opportunities that the platform offers.

\section{THE DEVELOPMENT OF E-LEARNING VERSUS INFORMATION SOCIETY}

The development of e-learning and the possibility of using this method of education are possible due to a wider access to computers and the Internet around the country. In a society that is willing to use instant messaging increasingly, and blogs or social networking sites, it is easier to encourage

\footnotetext{
${ }^{3}$ Ibid., p. 1
} 
people to broaden their knowledge through the use of online training. A graph presents the access to the Internet in Polish households.

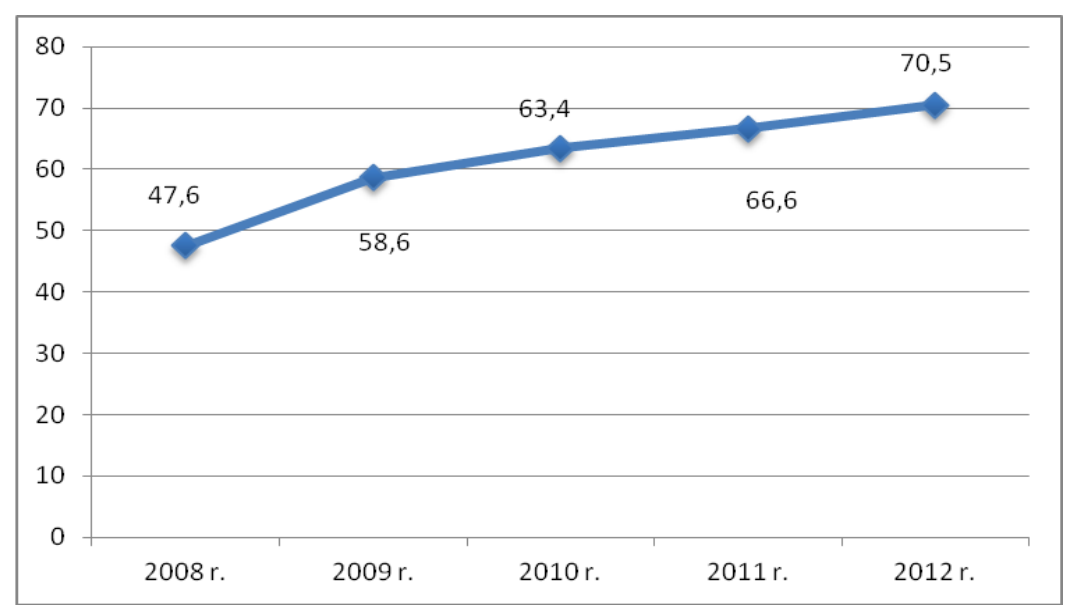

Figure 1. Number of households with Internet access at home. The data is presented as $\%$ of total households in a given group, Source: Information Society in Poland. Statistical results from the years 2008-2012, the Central Statistical Office of Poland, Statistical Office in Szczecin, Warsaw 2012

In addition, two important factors influencing the possibility of the development of distance education are increasing: the number of people using computers and improving the level of skills as well as the range of usage of the Internet among students.

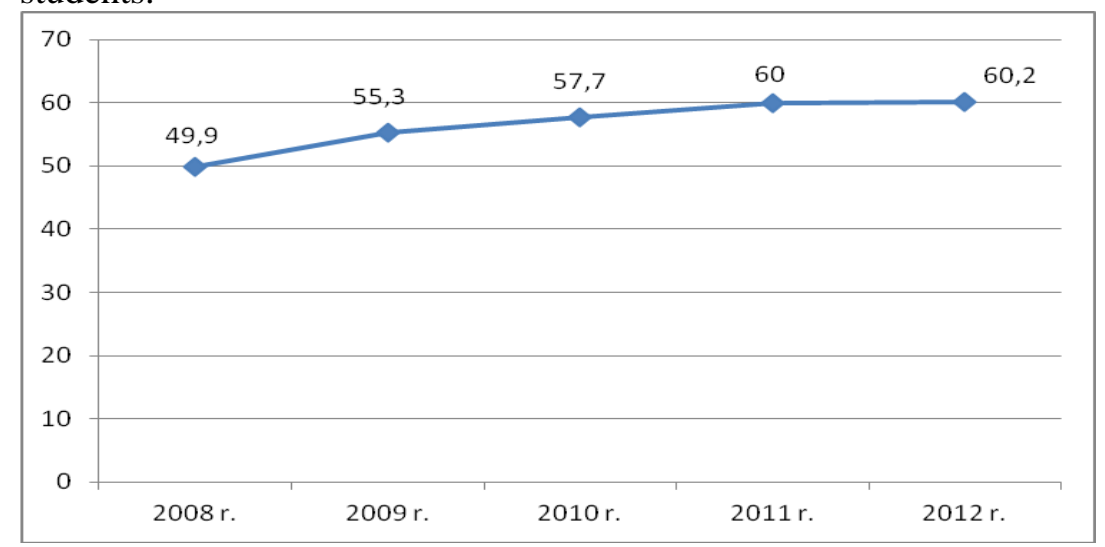

Figure 2. Number of persons who regularly use the computer. The data is presented as $\%$ of total population Source: Information Society in Poland. Statistical data for the years 2008-2012, the Central Statistical Office of Poland, Statistical Office in Szczecin, Warsaw 2012 
As shown in Figure 2 between the years 2008 - 2012 one can observe increasing number of people using a computer on regular basis. Figure 3 shows the percentage of people using the Internet by type of activity. The graph shows a minimal decrease in the use of the Internet as far as instant messaging and reading blogs are concerned. After a substantial increase within the number of people using chat rooms, participating in discussion forums or social networking sites in 2011, year 2012 can be perceived as a stabilization year in this respect. However, there was an increase in the number of people using the Internet to make phone calls. Nevertheless, the use of the Internet in these categories does not exceed $40 \%$ in any of the categories, which means that substantially less than half of the population is communicating through the Internet.

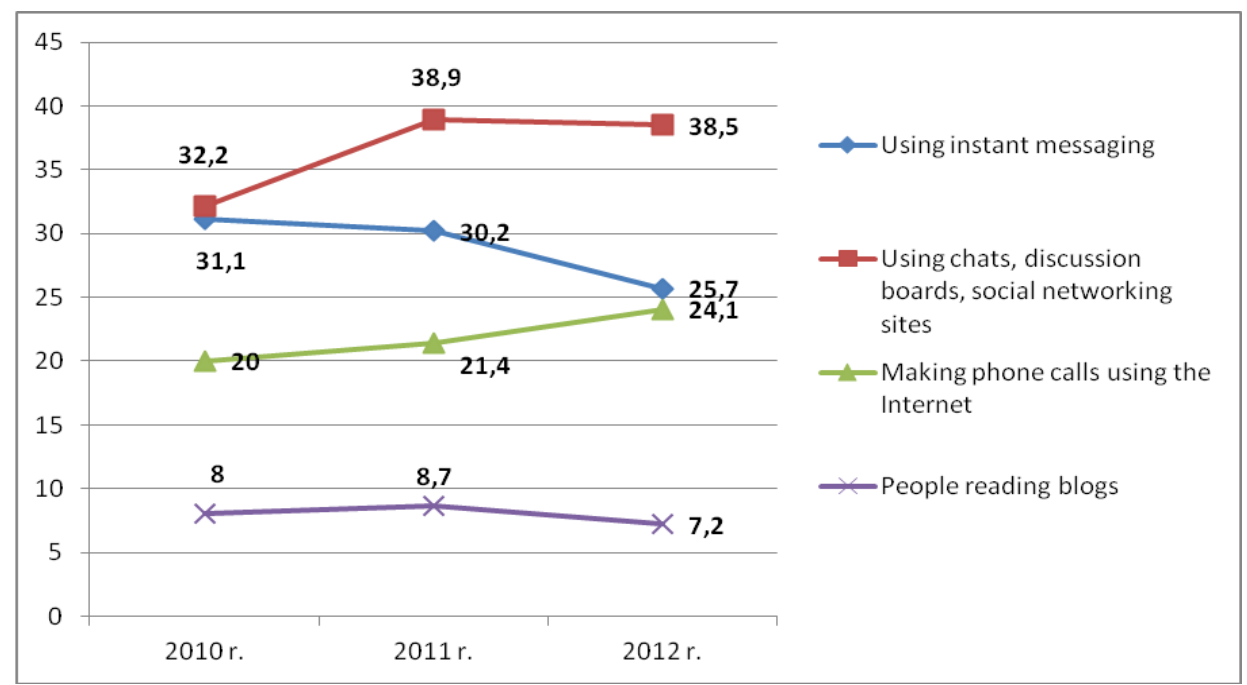

Figure 3. Number of persons using Internet communication services by type, data in $\%$ of the total population, Source: Information Society in Poland. Statistical data for the years 2008-2012, the Central Statistical Office of Poland, Statistical Office in Szczecin, Warsaw 2012

However, taking into account not the total number of members of population as it was shown in Graph 3, but the target group for e-learning, that is, pupils and students, the situation is improving considerably. Although a decline in the number of people using instant messaging and reading blogs can still be observed, significant growth can be perceived in terms of phone calls via the Internet, participation in chat rooms, discussion boards, social networking sites. Also, the number of members of this particular group as far as using the Internet is much higher. It should be noted that nearly half of pupils and students in 2012 make phone calls over the Internet, over $70 \%$ use instant messaging, and nearly 
90\% participate in chat rooms, discussion boards, or use social networking sites. The number of people reading blogs has decreased, but it is still more than $20 \%$ of pupils and students.

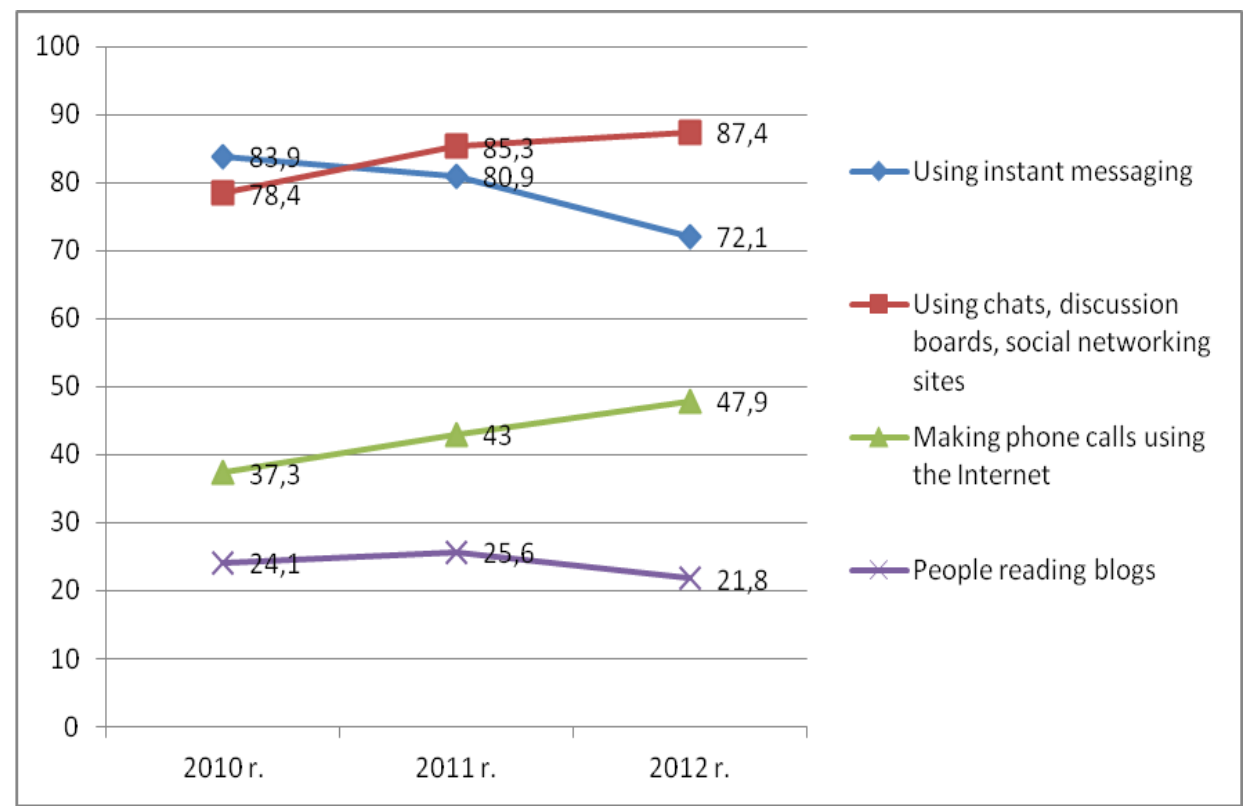

Figure 4. Number of persons using Internet communication services by type of group: Students and pupils, data in \% of the people in the group, Source: Information Society in Poland. Statistical data for the years 2008-2012, the Central Statistical Office of Poland, Statistical Office in Szczecin, Warsaw 2012

\section{DISTANCE LEARNING - A CASE STUDY OF ANDRZEJ FRYCZ MODRZEWSKI KRAKOW UNIVERSITY E-LEARNING PLATFORM}

Andrzej Frycz Modrzewski Krakow University e-learning platform started in 2011. In the academic year 2011/2012 first courses for full-time as well as parttime students were introduced. Teaching materials created by lecturers, whose supporting or subsidiary courses were to be run on the platform, undergo a certification process. The process includes formal assessment as far as the fulfillment of obligatory conditions is concerned, in accordance with the provisions in the relevant documents regulating the teaching process in the field of distance learning in terms of methodology, and non-infringement of copyright by third parties. E-learning University Center employs professionals who help with the graphics and the technical side of the prepared materials. Teaching materials are developed in SCORM 2004 standard, in the form that 
can be placed in a course as attachments or tasks. Each element of a course taught within the scope of a subject can be made available to students in selected dates, thereby stimulating the learning process. Students and teachers can communicate via instant messaging, discussion boards or messages sent from the platform on e-mail boxes as well as messages within the platform. Teachers have at their disposal a generator of e-learning courses. Therefore, they can prepare the content in the standard used on the platform. Also, it enables the lecturers to create interactive materials for students who can independently verify the knowledge they have acquired. In addition, the onscreen interactions help to systematize the teaching material.

Apart from the interaction in which a student is informed about the level of accomplishment of the task, the platform also provides its users with the opportunity of sharing descriptive tasks via the platform. In such tasks, students are asked to do some work, whose results they are required to pass to the teacher in a file on the platform. The teacher can assess the task by giving it a mark and confirming whether the job is classified or not. The assessment may also include a comment. It is very convenient for both parties as each one of them - both students and teachers immediately see the effects of their actions. Students see their ratings and comments immediately after the teacher has finished the evaluation process. Teachers see documents submitted by students. Hence, they know when any document was given to the evaluation and can evaluate it at any time. The only condition is that the teacher needs to have a computer with the Internet access. An undoubted advantage of working on the platform is that immediately after logging, students can see the courses they have covered in the course of their studies. They can always go back to the content discussed earlier. Teachers also see in which semesters the courses were run and what subject included particular teaching materials. Another element of the platform is statistics. It allows teachers to obtain a thorough analysis of student activities on the platform. The statistics may show e.g. time spent by a given student on the platform, marks obtained in the individual elements of the course, the result of the test - if it has been prepared by a teacher and taken by students. In case of classes that are run online frequently, such data is a useful source of information as it allows the teacher to monitor and assess students' involvement as well as determine to what extent they have had a chance to assimilate the knowledge presented in the course.

\section{SUMMARY}

At a university level distant learning is mainly associated with combining classes run in a traditional form in a lecture hall with online classes carried out by using an e-learning platform. The quality and the form of prepared materials depend not only on the learning content, but also on the graphics as well as 
multimedia side of the course, which is to be placed on the platform. Distant learning platforms that are used to carry out classes should not only have specific features, but also a user-friendly interface. Proper operation of the platform should be monitored continuously, as even the smallest technical faults and interruptions can cause discouragement among both students and teachers. However, regardless of the chosen platform, a method of preparing teaching materials or possibilities of communication between students and teachers, one should remember that in order to implement distance learning at universities, students and teachers must be encouraged and supported to use this form of education. Therefore, being convinced about its attractiveness and effectiveness, they may subsequently use it more often and willingly.

\section{REFERENCES}

Marek Hyla, Przewodnik po e-learningu, ABC a Wolters Kluwer business, Warszawa 2007r.

Information Society in Poland. Statistical results from the years 2008-2012, the Central Statistical Office of Poland, Statistical Office in Szczecin, Warsaw 2012.

Minister of Science and High Education's order of September 25th 2007 with supplement on conditions the fulfillment of which is necessary for conducting didactic activities using distance education methods and techniques, Law Gazette. Nr 188, item.1347, p. 1.

Ryszard Tadeusiewicz, Jan Kusiak, E-learning szansą wzbogacenia oferty edukacyjnej Uczelni, Biuletyn Informacyjny Pracowników Akademii Górniczo-Hutniczej nr 138, luty 2005 ISSN - 1425-4271.

Primljeno: 12.02.2013.

Odobreno: 25.02.2013. 